\title{
Quality Assurance in Higher Education as a Political Process
}

Worldwide Universities Network Initiative Ideas and Universities, May 29, 2009

Michael L. Skolnik Professor Emeritus University of Toronto 


\section{Quality Assurance - a major phenomenon (or}

preoccupation) in higher education

- A relatively recent phenomenon, in public systems of higher education

- Now, QA is a universal practice, involving similar models, methods, and processes

- Significant resistance to QA by faculty has been reported in some countries ("the resistance paradox", Anderson, 2006) 
In this presentation, I invite you to consider one question about QA in higher education ...

... and some of its implications 


\section{Is Quality Assurance in Higher Education}
A Technical
A Political
Process?
Or
Process? 


\section{What do I Mean by "Political"?}

- The exercise of authority or power - which tends to be distributed unevenly

- Public allocation of things that are valued

- Resolution of conflict

- Competition among individuals and groups pursuing their interests

Danziger (1994) 


\section{A few qualifications about the question}

- Not likely an "either-or" choice

- The balance between technical and political dimensions of QA likely vary by context

- Sometimes "small-p" politics is intertwined with "Large-P" politics 


\section{Some reasons to suspect a political}

\section{dimension in QA}

- Diversity of views as to what constitutes quality in higher education

- Pressures toward conformity in academe

- Uneven distribution of power among the stakeholders in the QA process, including particularly the tendency to exclude ordinary faculty from a significant role in the QA process 


\section{Conceptions of Quality in H.E.}

- Quality involves personal and social constructions that vary from stakeholder to stakeholder (Ratcliff, 2003)

- Ideas about quality appear to vary with world view, vantage point, values, educational philosophy, constituency, discipline, and gender

- Different conceptions of quality serve different interests and constituencies 


\section{Common conceptions of quality}

- Resources

- Admissions selectivity

- Faculty publications and research grants

- Educational processes and requirements

- Student learning outcomes (and valueadded)

- Characteristics of the student experience (e.g. student engagement) 


\section{Quality as Conformity to Orthodoxy}

- Kuhn (1962) described how the tendency toward conformity is manifested within a field of study through collegial processes

- That danger is magnified and the consequences made more serious by the imposition of a system-level or state-backed quality assessment system 
Example: The Research Assessment Exercise in Economics in the UK (Harley and Lee, 1997; Lee, 1998; Lee and Harley, 1998; Harley, 2002; Lee, 2007)

Shows the systematic bias against nonmainstream economics and economists in the QA process (Institutional, PostKeynesian, Radical, Sraffian, Marxist) 
Harley and Lee looked at the way that assessment panels were formed and the weight given to different journals

- mainstream economists captured the QA process; and

- imposed their paradigm-bound view of quality, with the result being reduction of diversity of economics 


\section{To Centralize QA or Not?}

- Lee and Harley show the downside of a decentralized process - e.g., no one to check on fairness

- A centralized system is also open to the problem of paradigmatic bias. Example: quality judged by conformity to natural sciences paradigm (Skolnik, 1989) 


\section{Other perceptions of the political}

nature of quality assurance

6 ..... quality assurance in the contemporary university is not a neutral or value-free concept, but a process reflecting a particular powerknowledge regime." (Anderson, 2006) 
... and

"Quality assurance is a socially constructed domain of power." (Morely, 2003) 


\section{Another Aspect of the Political Nature}

of QA: Faculty Role in the Process

In external QA, often it is limited to:

- Complying with requests for data

- Awaiting judgments that impact their careers

- Negligible opportunity for input, explanation or appeal

- Note the contradiction with norms regarding faculty role in governance in academe 


\section{Faculty attitudes towards external}

quality assurance

- Some surveys show substantial numbers with negative attitudes and perceptions (Harley, 2002; Anderson, 2006; Morely, 2003)

- Themes: powerlessness; control and discipline; serving managerial rather than academic ends; privileging some knowledge and methodologies over others

- Harley: Majority felt that changes in their discipline resulting from QA were "bad" 


\section{Purposes Served by Quality Assurance}

- Accountability

- Control

- Compliance

- Improvement

"The rhetoric . . . in many countries refer[s] to quality evaluation as a process of improvement, yet all the emphases are on accountability, compliance and, in some cases, control of the sector" (Harvey and Newton, 2004, 151). 


\section{Are faculty part of the problem or part}

of the solution?

"...genuine quality enhancement can only be fully sustained if it is premised on the energies and initiatives of frontline academics..." (Newton, 2000)

"We believe ... that the most needed reform is the renewal of internal mechanisms for quality assurance in colleges and universities..." (Dill, Massy, Williams, and Cook, 1996) 


\section{Paradox of QA and faculty}

Believing that faculty commitment to QA is important, on the one hand, and on the other, employing a process that, according to some observers, has as its goal "the correction and rehabilitation of faculty", and reportedly, excludes or marginalizes, and often demoralizes, faculty 


\section{An alternative evaluation paradigm?}

- Rather than following an approach that ignores, or denies, the political dimension of QA ...........

- How about finding an approach that is appropriate to a political process? 


\section{Learning from the Field of Evaluation}

- QA involves evaluation

- Evaluation has a well developed body of theory and professional practice, with its own scholarly journals and scholarly associations

- QA in Higher Education seems to have developed on its own largely in isolation from the scholarly and professional field of evaluation - little cross-referencing 


\section{QA \& Field of Evaluation}

"Relative even to where the field of evaluation was several decades ago, the typical evaluation of faculty or program quality in most universities could only be described as employing a worst-practice methodology" (Skolnik, 2000).

". . . the methodology of QA is perceived as taking the academy backwards in terms sophistication of analysis" (Morely, 2003) 
Four Generations of Evaluation (Guba and Lincoln, 1989)

1. Evaluation as Measurement

2. Evaluation as Description

3. Evaluation as Judgment (introduction of standards)

4. Responsive Evaluation (see Stake, 1975; 2004) 


\section{Problems of the First Three Generation \\ Models}

- Managerialism

- Manager stands outside the evaluation but might be the problem

- Disempowerment of other stakeholders

- Failure to recognize competing values, perceptions, and interests 


\section{Characteristics of Fourth Generation}

\section{Evaluation}

- Starting point: claims, concerns, and issues put forth by all stakeholder groups

- Value-pluralism

- Employs a Constructivist Paradigm as an alternative to a Positivist Paradigm

- Evaluator as mediator \& negotiator

- Evaluation as a collaborative process

- Postmodernist Evaluation (Mabry, 2003) 


\section{Looking at QA in Higher Education}

through the Lens of Evaluation Models

- As QA developed in the 1970s and 1980s, the Judgment Model predominated

- Judges drawn primarily from an academically conservative elite

- Judges imposed their own fairly narrow view of academic quality that emphasized:

inputs, (unverified) instructional process criteria, admissions selectivity, and research reputation 


\section{Looking thru the Evaluation Lens, 2}

- The Accountability Movement of the 1990s and the rise of the Measurement Model

- Performance Indicators

- Measurement of student learning, ironically taking us full circle back to the origins of the field of Evaluation 


\section{Looking thru the Evaluation Lens, 3}

- Little Adoption of the Responsive Model

- This, in spite of the growing prominence of Constructivist and Postmodern orientations in universities and colleges

- Perhaps the power over QA rests with those who have more affinity with neoliberalism (Peters and Olssen, 2005), than with postmodernism

- Perhaps too, the influence of the natural sciences is partly responsible 


\section{Conclusions: Some Challenges}

- Accept the political dimension of QA

- Clarity about objectives of QA initiatives ask how they promote improvement

- Recognize and accommodate diversity of views about Quality

- Connect with the field of Evaluation

- Involve faculty and other stakeholders in a meaningful, collaborative way 
The responsive model could provide a way to usefully open up QA

“. . . Until university management, university quality agencies and academic staff in universities draw on mutually agreed understandings of this contested concept academic quality - academics will continue to resist quality processes, treating them as games to be played and systems to be fed" (Anderson, 2006). 


\section{References}

Anderson, G. (2006). Assuring quality/resisting quality assurance: academics' responses to quality in some Australian universities, Quality in Higher Education, 12(2), 161-173.

Danziger, J.N. (1994). Understanding the political world. second edition. New York: Longman.

Dill, D.D., Massy, W.F., Williams, P.R., and Cook, C.M. (1996). Accreditation \& academic quality assurance, Change, September/October, 17-24. 


\section{References, continued}

Guba, E.G., and Lincoln, Y.S. (1989). Fourth generation evaluation. Newbury Park, CA: Sage Publications.

Harley, S. (2002). The impact of research selectivity on academic work and identity in UK universities, Studies in Higher Education, 27(2), 187- 205.

Harley, S. and Lee, F.S. (1997). Research selectivity, managerialism, and the academic labor process: the future of nonmainstream economics in U.K. universities, Human Relations, 50(11), 1427-60.

Harvey, L., and Newton, J. (2004). Transforming quality evaluation, Quality in Higher Education, 10(2), 149-165. 


\section{References, continued}

Kuhn, T.S. (1962). The structure of scientific revolutions. Chicago: University of Chicago Press.

Lee, F.S. (2007). The research assessment exercise, the state and the dominance of mainstream economics in British universities, Cambridge Journal of Economics, 31(2), 309-325.

Lee, F.S. and Harley, S. (1998). Economics divided: the limitations of peer review in a paradigm-bound social science, in D. Jary and M. Parker (eds.). The new higher education: issues and directions for the post-Dearing university. Stoke-on-Trent: Staffordshire University Press, 185-204.

Morely, L. (2003). Quality and power in higher education. Buckingham, UK: Society for Research into Higher Education and Open University Press. 


\section{References, continued}

Newton, J. (2000). Feeding the beast or improving quality? Academics perceptions on quality assurance and quality monitoring, Quality in Higher Education, 6(2), 153-163.

Ratcliff, J.L. (2003). Dynamic and communicative aspects of quality. Quality in Higher Education, 9(2), 117-131.

Skolnik, M.L. (1989). How academic program review can foster intellectual conformity and stifle diversity of thought and method in the university, The Journal of Higher Education, $\quad 60(6), 619-$ 643. 


\section{References, continued}

Skolnik, M.L. (2000). Does counting publications provide any useful information about academic performance, Teacher Education Quarterly, 27(2), 15-26.

Stake, R.E. (2004). Standards-based and responsive evaluation. Thousand Oaks, CA: Sage Publications. 


\section{Contact Information}

Michael L. Skolnik

Department of Theory \& Policy Studies

Ontario Institute for Studies in Education

of the University of Toronto

252 Bloor Street West

Toronto, Ontario

Canada M5S 1V6

Email: mskolnik@oise.utoronto.ca 